\title{
Interaction between a propagating cave and an active pit at Telfer Mine — Part I: interaction management
}

\author{
U. Singh Newcrest Mining Limited, Australia \\ R.A. Dixon Newcrest Mining Limited, Australia \\ C. McArthur Newcrest Mining Limited, Australia
}

\begin{abstract}
The Telfer Underground Sublevel Cave (SLC) Operation is located approximately $800 \mathrm{~m}$ below the West wall of the Main Dome Open Pit. The Telfer SLC initiated in late 2006 and is caving successfully at a global rate of approximately $0.6 \mathrm{~m}$ per day. The cave is expected to break into the planned 5384 bench on the West wall of the active Main Dome pit which has a haul ramp running along the wall at approximately $70 \mathrm{~m}$ horizontal distance from the edge of the cave.

The breakthrough area of the pit was being mined as the cave was propagating, requiring assessment of the potential for rapid propagation and unexpected subsidence. The key trigger points for evacuating and barricading the breakthrough area were based on monitoring of the cave propagation, the calculation of air gap and risk assessment of the interaction. Monitoring of key parameters was critical for informed decision making and safe management of the interaction between the cave and the pit.

Part I of this paper discusses the risk management strategy and tactics used for managing the interaction, including implementing a second ramp, preloading the breakthrough area and setting up a major hazard management plan. A trigger, action, and response plan is also used to monitor key parameters, identify predetermined triggers and take the designated action.
\end{abstract}

\section{Introduction}

Telfer Operations has a sublevel cave mine operating approximately $800 \mathrm{~m}$ below an active pit. The West wall of the pit was being mined while the cave was propagating up towards it. The propagating cave is expected to hole into the Western wall of the pit close to a haul ramp. The main haul ramp is located approximately $70 \mathrm{~m}$ away from the breakthrough area. The planning and management of the interaction between the propagating cave and operating pit is discussed in Part I of this paper. Part II discusses the instrumentation and monitoring undertaken to track the cave and provide data for managing the hazards.

\subsection{Telfer operations}

The Telfer Gold Mine is a Newcrest Mining Ltd owned operation located approximately $1,300 \mathrm{~km}$ north of Perth and $450 \mathrm{~km}$ East of Port Headland. The operation comprises of two mines, the Telfer Open Pit and the Telfer Underground (Newcrest Mining Ltd, 2009). The Telfer Open pit is currently mining in the Main Dome Pit which is located approximately $800 \mathrm{~m}$ above the underground operations. The operation produces approximately 630 ounces of gold and 33,000 $\mathrm{t}$ of copper per annum.

The Telfer open pit is mined using conventional truck and shovel methods and is planned to be mined to a depth of $650 \mathrm{~m}$. The underground is mined by SLC method using an underground crusher and shaft haulage to produce approximately 5.6 million tonnes of ore per year.

The deposit is hosted in concordant, bedding parallel reefs overprinted by late stage discordant veins, breccia zones and stock-work within the pelitic sediments of the Main Dome (Figure 1). The mineralisation extends vertically for over 1,500 $\mathrm{m}$ through the Telfer and Malu formations. The Stratigraphy is folded through a few episodes where a monoclinal fold is overprinted by a Telfer Dome folding event. A large fault zone, the Graben Fault, is located on the southeastern edge of the SLC, trending away towards the North. A brief 
description of the geology and rock mass properties is provided in a paper by Di Giovinazzo and Singh in these proceedings (Di Giovinazzo and Singh, 2010).

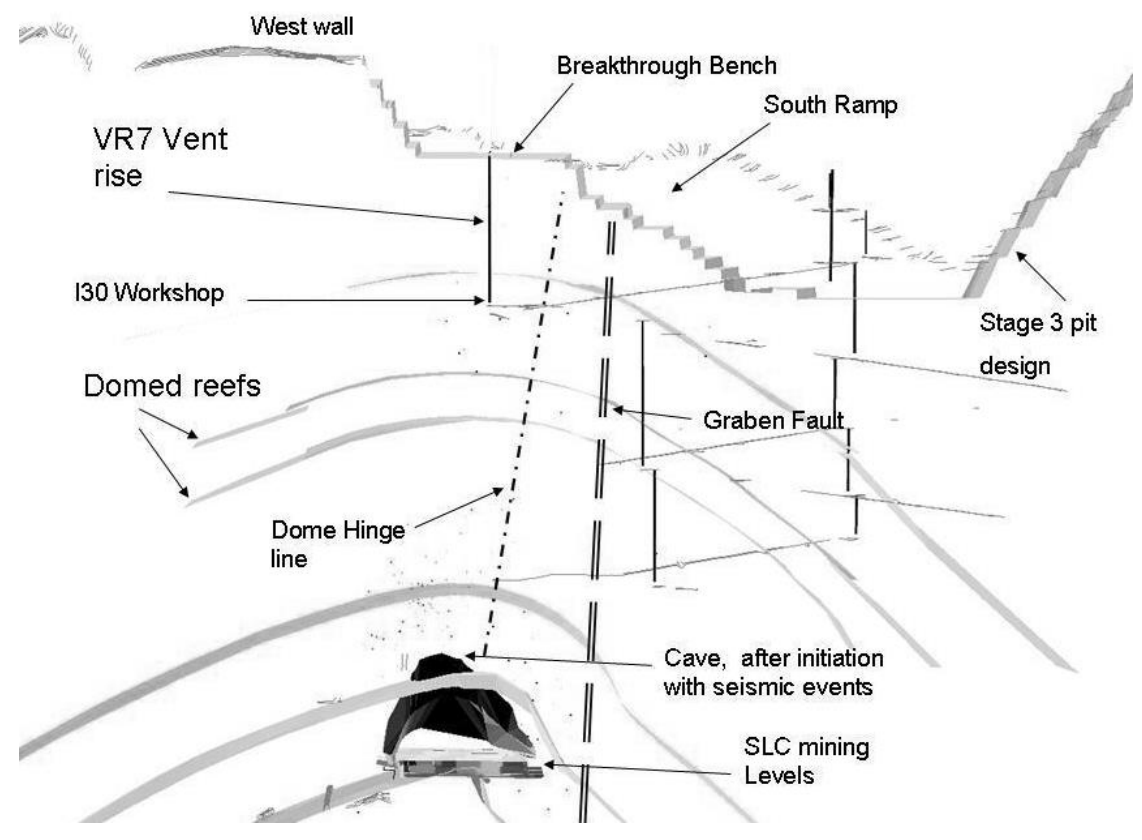

Figure 1 Section view looking north showing selected dome structures, the SLC, the Graben Fault and the dome hinge line

\subsection{Pit planning}

The Telfer Main Dome Pit was designed to have the SLC cave break into the Western wall of the stage 3 pit. A breakthrough bench was planned on the $5384 \mathrm{~m}$ RL which was prepared as a large flat area to contain the cave. This area was also used for instrumentation and monitoring of the cave and preloading of waste material above the planned cave apex.

The main stage 3 pit haul ramp (South Ramp) also ran along the Western wall and is about $70 \mathrm{~m}$ away from the breakthrough zone. As a risk mitigation measure, a secondary haul ramp was installed in the Northern sector of the pit to provide an alternative haulage route.

After the SLC operations are completed and the cave has stabilised, the pit is planned to be cut back through the Western wall and the cave itself. To facilitate this, the surface area proximal to the cave was preloaded and the subsidence crater was to be backfilled from the Western wall. This preloading and backfilling was designed to provide confinement to the Western wall and crater in order to limit the crater size and wall sloughing. The preloading and backfilling is conducted using in-pit waste which has the secondary benefit of reducing haul distance for the waste.

\subsection{Cave monitoring}

Cave monitoring was required to determine the shape and size of the cave apex, its propagation rate, location relative to the pit and potential air gap at the apex. While the cave was more than $300 \mathrm{~m}$ from the pit the monitoring was conducted primarily through extensometers and the microseismic array located underground.

Surface monitoring consisting deep-hole extensometers were installed from the breakthrough bench to approximately 300 depth (Figure 2). The drilling and installation of the surface extensometers required careful scheduling as the pit was being mined in the breakthrough vicinity at the time and there were concerns about the drill rig interacting with mining activity. Early drilling also had the potential to expose the holes and hole collars to blast damage. For this reason it was also not practical to install the instruments until mining had progressed past the breakthrough bench horizon. Open holes and an old vent rise (VR8) which connected the cave to the surface were also used for camera surveys of the cave. A detailed description of the instrumentation and monitoring is provided in Part II of this paper (Dixon et al., 2010). 


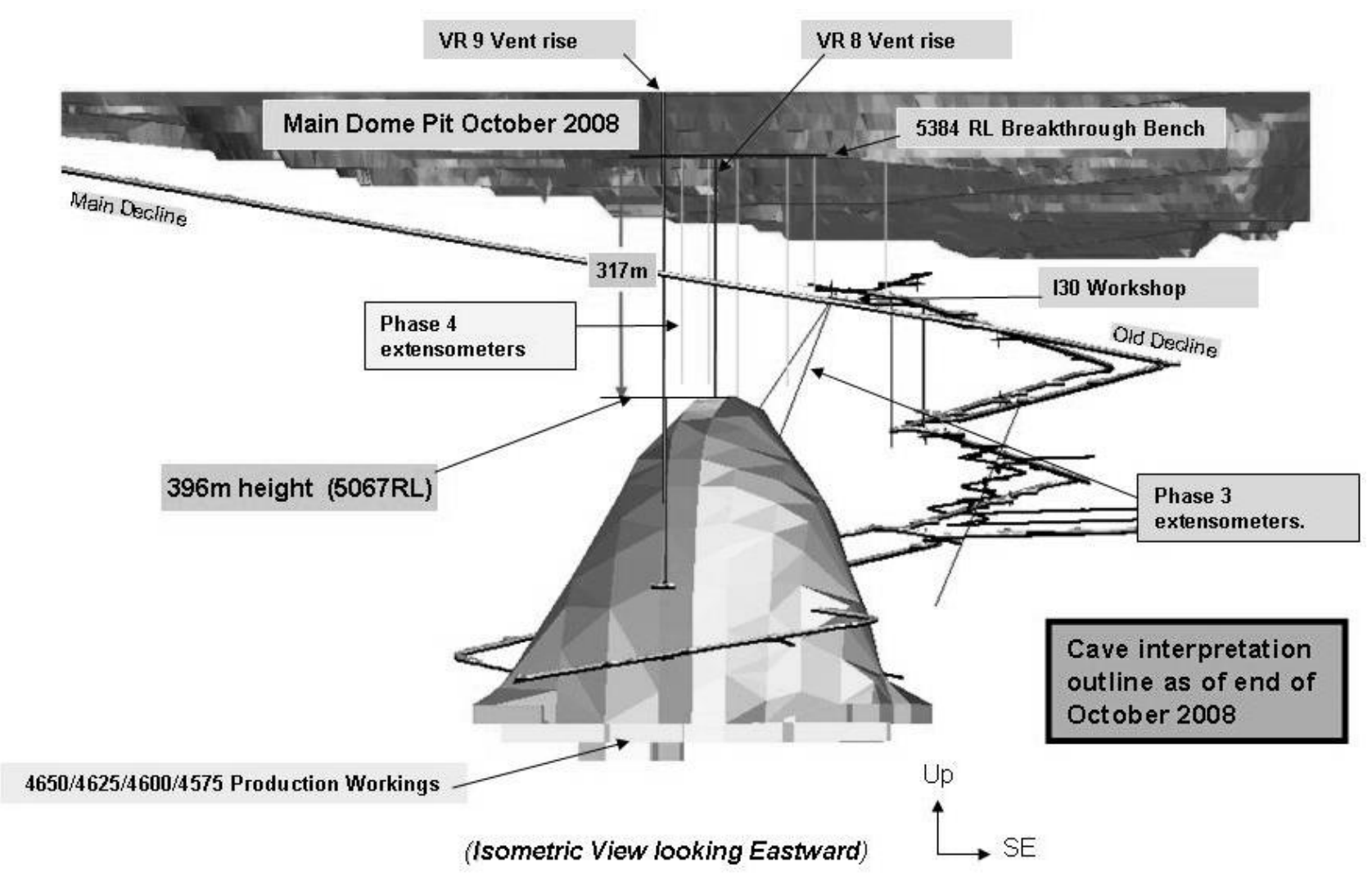

Figure 2 Side view looking showing the cave, pit and instrumentation for the interaction. Note that the Phase 3 extensometers where installed from the I30 workshop underground and the Phase 4 extensometers from the breakthrough bench

Open holes and an old vent rise (VR8) which connected the cave to the surface were also used for camera surveys of the cave. A detailed description of the instrumentation and monitoring is provided in Part II of this paper (Dixon et al., 2010).

\section{Interaction between the cave and the pit}

The Telfer SLC cave initiated in late 2006 and has been caving successfully at a global rate of around $0.6 \mathrm{~m}$ per day. The cave propagation rate and cave apex position are assessed using seismic data, long hole extensometers and dipping of open holes.

The cave back was modelled in Datamine using the SLC extraction schedule and some gross assumptions on swell factor of caving material in order to schedule the interaction. The results had wide variance due to the magnified impact of small changes in bulking factors and changes in caving hydraulic radii with changing stratigraphy. The SLC also mines over a long strike length of approximately $800 \mathrm{~m}$ and the extremities stepped out for each level that is mined down (Di Giovinazzo and Singh, 2010). This adds complications to the cave propagation as mining conducted at the extremities do not always have a direct impact on cave apex movement. As the cave progressed more data was obtained providing improved understanding of caving rates and cave behaviour.

The cave was also propagating adjacent to the Graben Fault (Figure 1), raising the possibility of fault related movement in the pit and subsidence along the fault if the cave intersected the fault.

The Telfer cave has successfully propagated to the surface and holed into the breakthrough bench in October 2009 , within $50 \mathrm{~m}$ of the planned breakthrough location. 


\subsection{The diminishing pillar}

Mining activity was being carried out above the cave apex whilst the cave was propagating. It was important to delineate an exclusion pillar such that activity above the cave could be carried out safely without risks from the cave. A pertinent question at the time was:

\section{"What is the safe design pillar for working above the cave."}

The diminishing pillar is essentially an unstable entity as it is designed to cave. Therefore the use of pillar stability design criteria was not appropriate for this situation. Flores and Karzulovic (2000) discussed these concepts in the International Caving Study II Report. They proposed an empirical design method for assessing the minimum pillar thickness for which pit operations could be conducted above the cave. This method is generic in nature and the authors do emphasise that it should not be used where detailed information is available, however, it provided a useful ballpark figure of what minimum pillar may be suitable for Telfer. Using empirical analysis methods detailed in the ICS-II, Task 4 Report the minimum crown pillar required for working on the preloading bench was $100 \mathrm{~m}$. If the cave interacted with a fault then the minimum pillar thickness would be $150 \mathrm{~m}$. A factor of safety of 2 was applied to this worst case scenario in order to provide a conservative 'exclusion pillar' of $300 \mathrm{~m}$.

The more relevant question to ask at the time was:

\section{"At what point in the cave propagation do we trigger a potential for uncontrolled movement in the pit above the cave?"}

This point where the potential exists would be a point at which the probability of cave propagation causing uncontrolled movement or surface subsidence is greater than zero. Uncontrolled propagation was defined as cave propagation or rock subsidence that could not be controlled by stopping the SLC draw. Furthermore it could not be measured and forecast with sufficient accuracy so as to enable the safe evacuation of personnel and equipment from the pit above the cave with a minimum 24 hour notice.

The other question of interest was:

\section{"Just how much surface subsidence is considered significant enough to cause serious injury?"}

This question could not be answered without a risk assessment to analyse the activities being carried out, the potential hazards therein and adequacy of controls. For the purposes of hazard management at Telfer it was proposed that if uncontrolled propagation of the rock above the cave were to reach the pit then this would be unacceptable. In fact the pit operations would be able to tolerate some deformation, the magnitude of which would depend on the type of activities occurring in the pit, stand-off from the pit walls, the condition of the pit walls, weather (rainfall), seismic activity, in-pit monitoring instruments, alarms, triggers and response procedures etc. These tolerances and controls were to be determined through a risk assessment.

Given the above definitions, the key consideration for achieving uncontrolled propagation was the size of the air gap in the cave. If the cave was choked then the rate of cave propagation would be directly related to the draw underneath the cave and could be controlled. However, if an air gap existed then there would be potential for the cave to instantaneously propagate to a maximum height dictated by the swell of the failing rock and the volume required to choke the cave. Therefore a simple relationship could be drawn between the two. For a $300 \mathrm{~m}$ pillar and a conservative swell factor of $10 \%$ (actual was closer to $14 \%$ ), at least a $30 \mathrm{~m}$ air gap would be required for the subsidence to reach the surface. In reality, given the competent rock mass above the cave, an instantaneous propagation would have been exceedingly rare.

The seismic activity at the cave apex was closely related to the cave draw. No draw during shutdown periods significantly reduced the seismic activity directly above the apex (Dixon et al., 2010). This suggested that the cave apex was either choked or that the air gap was quite small. In this scenario it was possible to draw a relationship between the tonnes that needed to be extracted to produce the required air gap if the cave were to stall.

However, the height of the air gap for a given volume extracted depended on the cross sectional areas of the cave near the apex. This was not known but was assumed to be less than the undercut footprint and related to the caving hydraulic radius of the rock at the cave apex, the induced stress and seismic deformation. It was also difficult to determine how draw in the SLC step-out areas would affect cave propagation as some of the 
draw below the edges of the undercut were directly connected to the cave apex while draw further away was not. Assuming that $75 \%$ of the production would impact on the cave apex, a relationship between days of production required to create a given air gap and the cave back hydraulic radii was drawn up.

In order to cause breach of the $300 \mathrm{~m}$ pillar, a $30 \mathrm{~m}$ air gap was required (Figure 3a) and for a scenario of caving at hydraulic radius of 20, this would mean that the cave would be stalled for 32 days at current production rates (Figure 3b), which would be indicated by lack of movement of the seismogenic zone. This correlation was relevant as long as seismic activity was dependent on draw rate. If seismic activity at the apex became independent of draw rate then it would no longer be reliable information for assessing air gap.

\section{Potential Instantaneous Collapse Height}

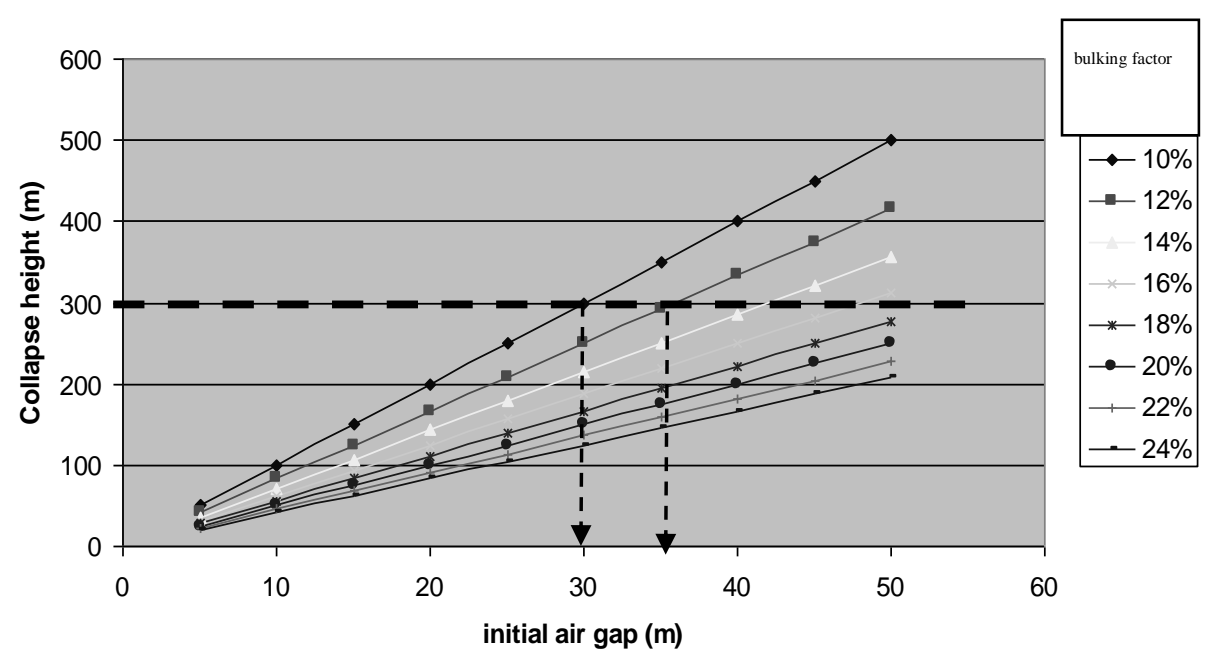

a)

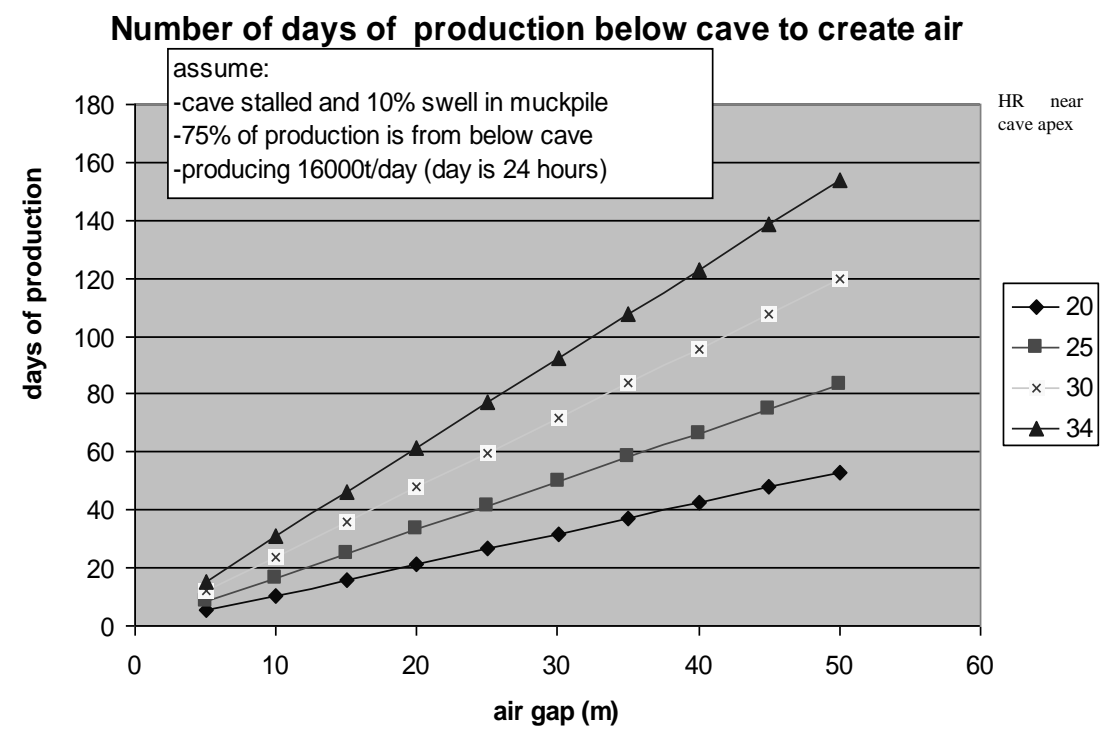

Figure 3 a) Air gap required for worst case collapse scenario; and b) estimated days of production to create a given air gap

Finite element modelling conducted by Beck Arndt Engineering in 2008, which was not calibrated for near surface movement, indicated that the cave would create a minor impact on the Western wall of the pit when the pillar was within $200 \mathrm{~m}$. This impact was not measured in the pit wall. The camera survey of the VR8 rise and interrogation of extensometer data did not show damage in the core of the pillar. Subsequently the model was calibrated when surface extensometer data became available and this was used to assess the size and extent of surface deformations. 
The potential for large plug type failure was not identified as a significant problem for this pillar thickness given that the rock mass was competent, did not have large subvertical faults and the cave had not intersected the Graben Fault. There was also a potential for the cave to deviate and propagate along the stratigraphic hinge line and move towards the Graben Fault in which case the cave rate could have increased significantly causing an early breach, and the locality of the cave breach would have been further East towards the Haul Ramp. Extensometers were installed from the upper levels of the old underground workings (I30 Workshop) to monitor cave deviation towards the Graben Fault and any movement on the fault.

\subsubsection{Before $300 \mathrm{~m}$ pillar breach}

The above pillar analysis was rudimentary but also quite conservative. The exclusion pillar, located $300 \mathrm{~m}$ below the breakthrough bench was designed as a 'hold and review point' for verifying that all the necessary risk assessments and controls were in place and for escalating the monitoring and control procedures for working above the cave.

Whilst the cave was more than $300 \mathrm{~m}$ from the pit breakthrough the following triggers were used:

- if the cave apex did not propagate for 30 consecutive days than an alert would be triggered which would include the potential collapse height and proximity of this to the pit (Figure 3)

- this alert would be submitted to the underground and open pit managers and head of production

- if the potential collapse height was interpreted to reach the pit then the breakthrough bench would be evacuated until such time that cave propagation had recommenced or the air gap could be measured with confidence and potential collapse height reinterpreted.

The following additional monitoring and trigger actions were implemented for the cave propagation up to the exclusion pillar:

- the cave apex position was interpreted and reported at least fortnightly

- the cave propagation rate was tracked and reported at least fortnightly

- a review of the data and hazards would be triggered if interpreted cave rates exceed $1.5 \mathrm{~m}$ per day for a month

- a review of the data and hazards would be triggered if cave propagation rates dropped below $0.2 \mathrm{~m}$ per day for a month.

When the cave reached the $300 \mathrm{~m}$ exclusion zone, the surface drill holes were to be used to measure the cave back position and any air gap. These measurements were to be used to calculate the potential collapse height and proximity to the pit. If the cave could not be directly measured then the breakthrough area above the cave would be cleared and cordoned off.

A specific cave-pit interaction project was set up to identify and mitigate risks related to the interaction. A list of actions was scheduled to be completed before the cave reached the exclusion pillar. These included completing mining activity on the breakthrough bench, contouring this bench for the breakthrough, drilling monitoring holes from this bench and installing extensometers.

\subsubsection{After the $300 \mathrm{~m}$ pillar breach}

The breach of the $300 \mathrm{~m}$ exclusion pillar required that all personnel and equipment be removed from the zone of influence if the following factors were not known with sufficient certainty:

- the location of the cave apex

- the rate at which the cave was propagating

- the extent of the cave (shape and size)

- the extent of air gap (gap between cave back and muck-pile).

If the above factors were known then it was feasible to continue working above and adjacent to the cave for a longer period with manageable risk. The controls required to work above the cave after pillar breach, and the 
minimum 'safe exclusion pillar' was to be decided through a separate risk assessment which would rely on the confidence in monitoring of the above factors and on the planned work activity (exposure) in the pit.

The following was determined before re-entry into the zone of influence after the cave breached the $300 \mathrm{~m}$ exclusion limit:

- The location of the cave apex. The cave apex was located inside a triangle bound by extensometers \#1, \#2 and \#3 and was very close to VR8 (Figure 3, Dixon et al., 2010).

- The rate of cave propagation was determined through correlation between seismic data extensometer readings and hole dipping.

- The extent of the cave shape was determined through seismic data and was not well defined in the cave flanks but was well defined at the cave apex due to correlation with extensometers and dipping of open holes (including VR8).

- The extent of the air gap was determined through camera survey of VR8 and interpretation of extensometer data. Minimum air gap was identified and this was supported by the correlation between seismic activity and draw.

A risk assessment was conducted following the pillar breach where the previous risk assessment was updated and new risks associated with backfilling of the cave were assessed. The cave monitors and status reporting was updated to weekly reports to be presented to the open pit supervisors.

The exclusion zone barricades and signage was erected and the trigger response plan updated to reflect additional controls as identified in the risk assessment (Figure 4). The major hazard management plan was updated accordingly. The authorised entry signs were placed further back to allow geotechnical personnel to travel up to the exclusion zone barricades for inspections.

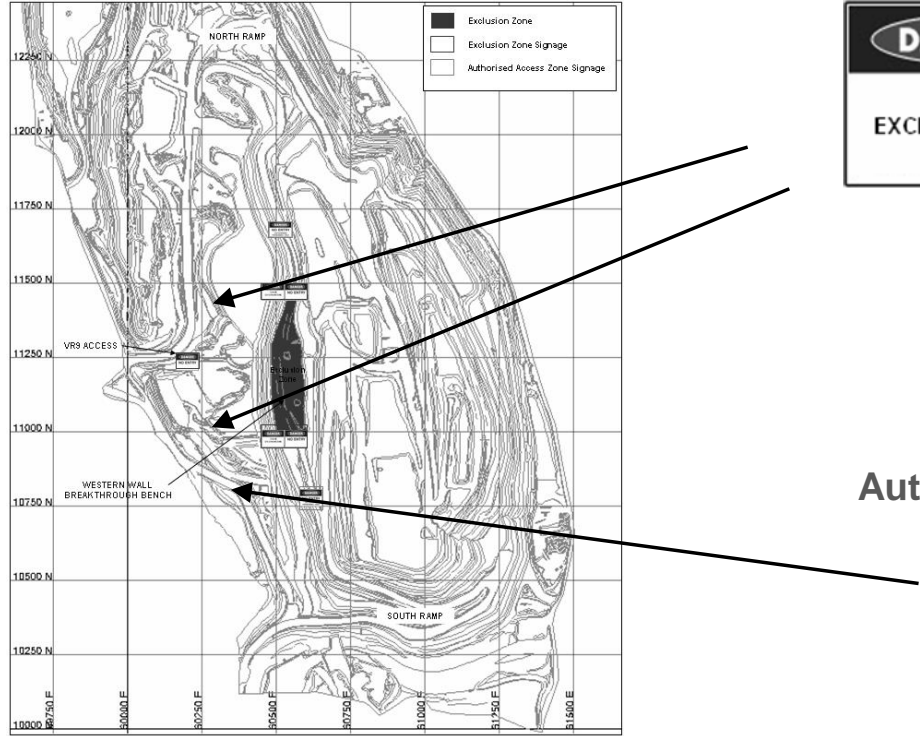

(a)

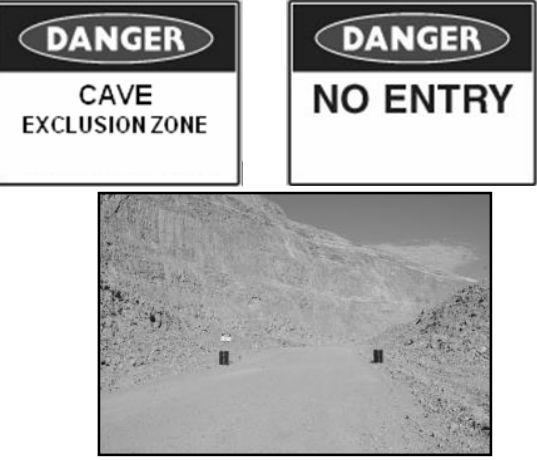

Authorised Access Area -

\section{DANGER}

\section{NO ENTRY}

AUTHORISED

PERSONNEL ONLY

Figure 4 Exclusion zone barricades and signage for the breakthrough area. (a) The cave breakthrough area was demarcated with signs and chained barricades; (b) signage used at the barricades

A further Pillar threshold was set at $200 \mathrm{~m}$. This threshold was to provide another hold and review point for reviewing the risks and controls of working on and around the cave pillar. When the cave breached the $200 \mathrm{~m}$ pillar, there was no surface disturbance, camera surveys of the pillar conducted through VR8 vent rise identified that the core of the pillar was intact and that there was no significant air gap. Preloading activities on the breakthrough bench were continued with the aim of completing all works and closing out the bench as 
soon as possible. The Trigger Action Response Plan (TARP) was updated and a further trigger threshold of $150 \mathrm{~m}$ was set. The monitoring and reporting requirements for the cave apex position, propagation rate, potential air gap and surface deformation was escalated to daily checks and updates at the prestart meetings with the data being reviewed twice daily.

The $150 \mathrm{~m}$ pillar was designated as the shut off point where the breakthrough bench must be barricaded off. All preloading works were completed before this threshold was reached and the breakthrough bench was barricaded off as planned. There was no surface deformation or instability of the Western wall during this period.

\subsection{Surface disturbance}

Once the cave breakthrough bench was barricaded off with 'no entry' signs, the TARP was modified into two sections. One section was for the impact on top of the Western wall and the other section was for movement on the South Ramp, below the breakthrough bench. The TARP was set up so that these areas could be closed off if the cave was likely to destabilise these walls, large seismic events occurred or if surface deformation exceeded set thresholds.

The pit wall and breakthrough bench were monitored for movement by installing prisms and using a radar monitoring system. There were a few complications in effective monitoring of the breakthrough bench as it was to be backfilled and the Western wall would also be eventually covered in backfill rill material. Prisms were installed along the edge of the breakthrough bench and on the accessible benches above and below. The radar was used to monitor the wall below the breakthrough bench as this wall was between the cave and the haul ramp and unravelling could impact the haul ramp. Extensometer \#7 (Figure 5) was the closest extensometer to the ramp and was located between the cave apex and the ramp. This extensometer was set up with a hold and review point for anchor \#10 (110 m below the cave bench) such that movement on this anchor would require a review of all the data and the TARP.

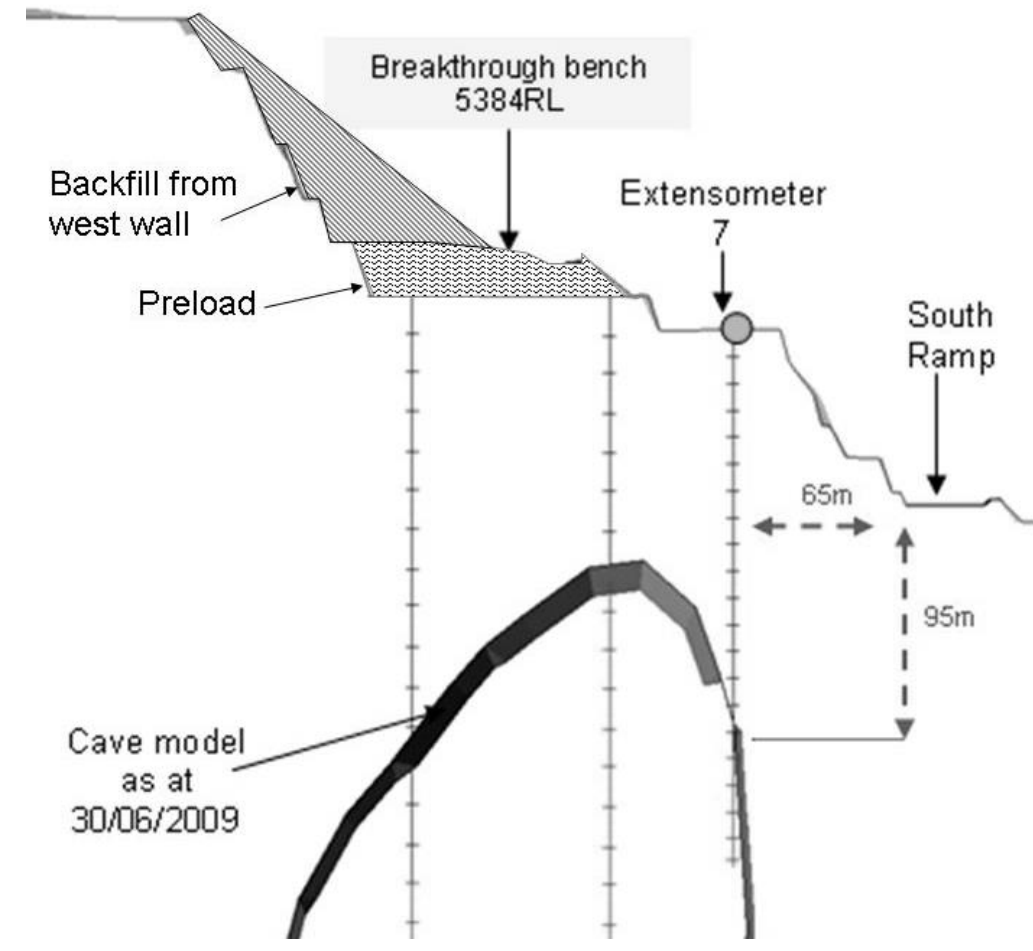

Figure 5 Section view showing proximity of the cave to the breakthrough bench and the South Ramp

On breach of this hold point, a risk review was carried out and the TARP for the South Ramp escalated to include triggers based on Radar movement and wall behaviour. The Radar trigger was set so that wall movement of greater than $1 \mathrm{~mm} /$ hour over a 12 hour period would require shutdown of the ramp. Any 
observations of cracking or rock fall from this area would also result in shut down of the ramp. Furthermore, a large seismic event (greater then local magnitude 1) would trigger the same.

\section{Major hazard management plan}

The Newcrest Safety and Health Management System required a formal major hazard management plan (MHMP) to be developed for each identified hazard that has the potential for the loss of one or more lives if the hazard eventuates.

The MHMP should list the key responsibilities for managing the hazard. Where the inherent risk is ranked as 'extreme' or 'high', a control management plan, showing the existing controls, must be included as part of the MHMP. After this, if the hazard remains 'extreme' or 'high', then a risk reduction Plan of additional actions to be completed must also be included to reduce the residual risk to an acceptable level within a prescribed time frame. A TARP is also required to flag key triggers and prescribe the minimum actions required, responsibilities and accountabilities for each action (Figure 6).

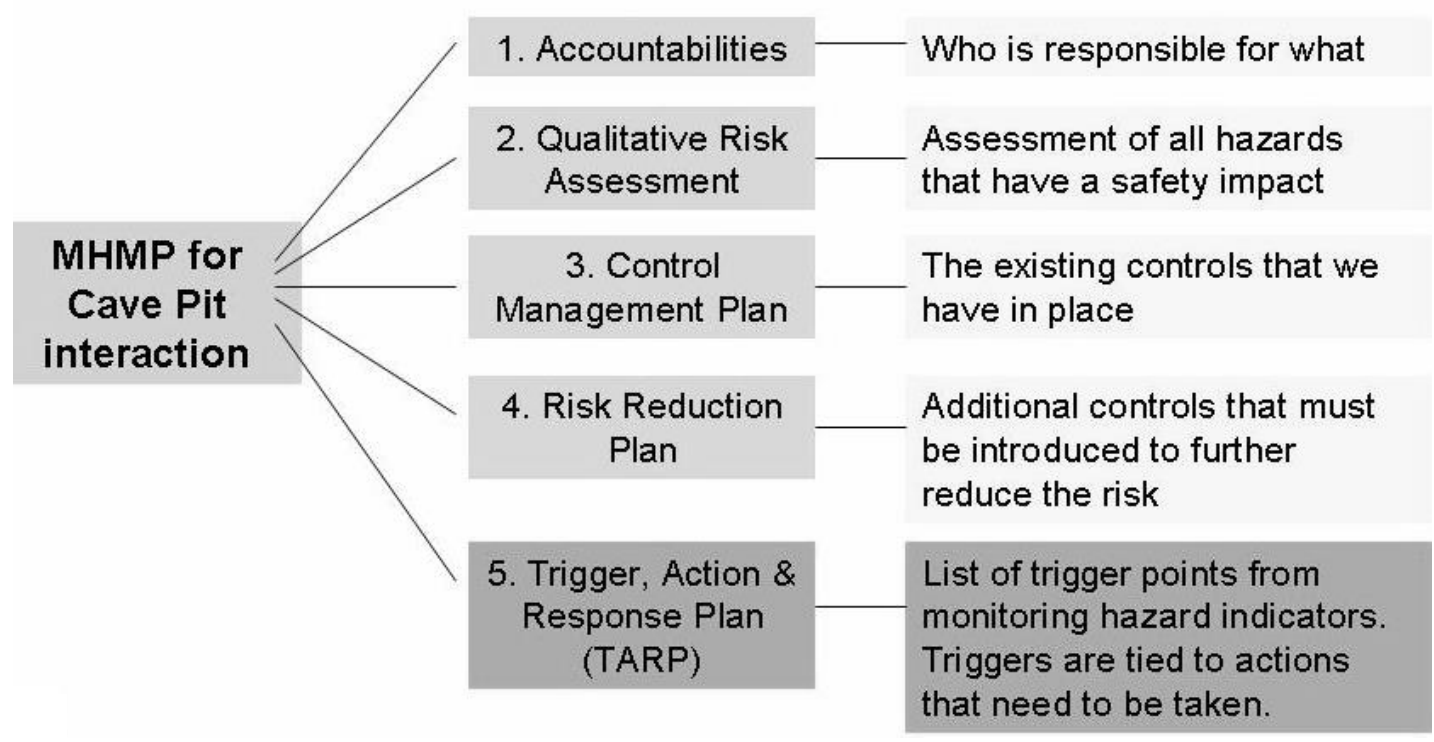

Figure 6 Summary of the MHMP contents

The MHMP for the cave-pit Interaction detailed the management requirements for those hazards assessed as 'high' or 'extreme' with respect to the impact of the SLC on the open pit. This plan is kept extremely focussed on the critical elements of controlling major hazards associated with the impact of the SLC cave on the open pit - additional data and detail were listed in the plan as key supporting documents and related references.

The plan summarised the critical elements of the:

- significant potential incidents (SPI) related to the interaction that have the potential to cause multiple fatalities

- contributing factors for the SPI's

- accountabilities for the monitoring, application and effectiveness of the current controls to prevent an interaction related SPI

- TARPs for the SPI's in order to detect signs and symptoms of a potential cave interaction related catastrophic event, and respond proactively before it occurs. 
Specific areas which are dealt with in this plan are:

- cave propagation up to the $300 \mathrm{~m}$ exclusion pillar to the open pit

- cave breaching the $300 \mathrm{~m}$ exclusion pillar

- cave breakthrough to the pit and subsidence in the pit.

Backfilling of the breakthrough bench was not addressed in the plan as it required a separate risk assessment involving issues such as working on a high wall and working near the pit edge.

The MHMP also had in built triggers for its review to ensure that the plan remained valid, appropriate and practical as circumstances change.

A risk assessment team was assembled on the 24th of January, 2004 to carry out a risk assessment on the impact of the Telfer SLC on the open pit. The risk assessment was conducted as per the Newcrest standard and facilitated by GHD Consultants The team worked through a time line of potential loss situations from when the cave was more than $300 \mathrm{~m}$ from the breakthrough to when the cave was within $300 \mathrm{~m}$ of pit, and when the cave broke through to the pit. Current controls related to the potential loss scenarios were identified, and recommendations for additional control procedures/measures drafted where the residual risks were high or the existing controls could be improved.

A hazard classification plan was drafted from this risk assessment to include all hazards which had a risk of 'extreme' or 'high'. An example of the hazard classification plan listing the existing controls and planned actions is shown in Figure 7.

\begin{tabular}{|c|c|c|c|c|c|c|}
\hline $\begin{array}{l}\frac{1}{N} \\
\stackrel{N}{N} \\
\frac{0}{2} \\
\overline{2}\end{array}$ & Hazard/ Step & Un-wanted Event & 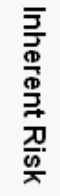 & $\begin{array}{l}\text { Existing } \\
\text { Controls }\end{array}$ & 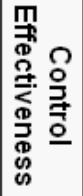 & $\begin{array}{l}\text { Risk } \\
\text { Reduction } \\
\text { Action }\end{array}$ \\
\hline 5.1 & \multicolumn{6}{|c|}{ Group B-Cave less than $300 m$ from breakthrough } \\
\hline B1 & $\begin{array}{l}\text { Cave related movement in pit } \\
\text { (wall) } \\
\text { Cave related movement on } \\
\text { Ramp } \\
\text { Cave related movement on } \\
\text { Pit Floor }\end{array}$ & $\begin{array}{l}\text { Rock fall related injury and/or } \\
\text { damage to equipment. }\end{array}$ & E4 & $\begin{array}{l}1,2,14 \\
6,\end{array}$ & 5 & $\begin{array}{l}78,60,57 \\
65,58\end{array}$ \\
\hline B2 & $\begin{array}{l}\text { Sudden displacement of vent } \\
\text { rise-connecting cave to } \\
\text { surface }\end{array}$ & $\begin{array}{l}\text { Struck by debris and dust } \\
\text { due to air blast venting } \\
\text { through rise. } \\
\text { Subsidence and/or sucked } \\
\text { into rise }\end{array}$ & E4 & 3,1318 & 9 & 59 \\
\hline B3 & $\begin{array}{l}\text { Cave deviates from planned } \\
\text { path (eg. Change in the rock } \\
\text { strata I rock mass } \\
\text { conditions) }\end{array}$ & $\begin{array}{l}\text { Instability due to movement } \\
\text { on Graben Fault (in ramp, } \\
\text { walls, bench). } \\
\text { (Safety issue) }\end{array}$ & E4 & $\begin{array}{l}4,5,13 \\
18\end{array}$ & 7 & $60,63,64$ \\
\hline B4 & Seismic Event & $\begin{array}{l}\text { Large Seismic event causes } \\
\text { shakedown in pit or causes } \\
\text { instability in the pit walls }\end{array}$ & $\mathrm{E} 2$ & $1,5,6,7$ & 6 & $60,18,36$ \\
\hline
\end{tabular}

Figure 7 An example of the hazard classification plan which list all risks that were identified as extreme or high

All the existing controls were listed in a control management plan to ensure that they were clearly identified and monitored for ongoing appropriateness and effectiveness. The control management plan also lists the personnel responsible and accountable for the actions, and a review requirement. A sample of the control management plan is shown in Figure 8. 


\begin{tabular}{|c|c|c|c|c|c|c|c|c|c|c|c|}
\hline & & & & $\begin{array}{ll}\text { Con } \\
\text { sssifi }\end{array}$ & itrol & & & & & & \\
\hline No & Existing Controls & H & $\mathbf{S}$ & \begin{tabular}{|l|}
$\mathbf{P}$ \\
\end{tabular} & M & $F$ & $\mathrm{R}$ & $\begin{array}{l}\text { Routine Control } \\
\text { Review }\end{array}$ & Responsibility & Frequency & Accountability \\
\hline 1 & $\begin{array}{l}\text { High-wall Procedures: } \\
\text { Hazard Management Plan with maps; } \\
10 \mathrm{~m} \text { standoff from all walls; } \\
30 \mathrm{~m} \text { for all vehicles \& equipment; } \\
\text { Spotters used within } 30 \mathrm{~m} \text { line; }\end{array}$ & & $x$ & $x$ & & & & $\begin{array}{l}\text { Inspect pit walls, } \\
\text { review work plans, } \\
\text { assess geotechnical } \\
\text { risks }\end{array}$ & $\begin{array}{l}\text { Senior } \\
\text { Geotechnical } \\
\text { Engineer OP }\end{array}$ & $\begin{array}{l}\text { At least weekly; } \\
\text { When seismic } \\
\text { event or rock fall } \\
\text { occurs. }\end{array}$ & $\begin{array}{l}\text { Manager Mining - } \\
\text { Open Pit }\end{array}$ \\
\hline 2 & $\begin{array}{l}\text { Safe Work Procedures, Driving Pit Permit, } \\
\text { Inductions }\end{array}$ & & $x$ & $x$ & & & & $\begin{array}{l}\text { Inspections; } \\
\text { Task observations }\end{array}$ & $\begin{array}{l}\text { Open Pit } \\
\text { Supervisor }\end{array}$ & daily & $\begin{array}{l}\text { Mining OP } \\
\text { Superintendent }\end{array}$ \\
\hline 3 & $\begin{array}{l}\text { Demarcation and bund set up at crest of rill } \\
\text { cone around rise } e_{s .}\end{array}$ & $x$ & $x$ & $x$ & $x$ & $x$ & & $\begin{array}{l}\text { Inspections and } \\
\text { status reports. }\end{array}$ & $\begin{array}{l}\text { Void Control } \\
\text { Officers }\end{array}$ & Daily & $\begin{array}{l}\text { Manager Mining - } \\
\text { Open Pit }\end{array}$ \\
\hline 4 & $\begin{array}{l}7 \times \text { Surface monitoring holes with } \\
\text { extensometers and one open hole }\end{array}$ & & $x$ & $x$ & $x$ & & & $\begin{array}{l}\text { Inspect for damage } \\
\text { and changed } \\
\text { conditions }\end{array}$ & $\begin{array}{l}\text { Senior } \\
\text { Geotechnical } \\
\text { Engineer OP }\end{array}$ & Daily & $\begin{array}{l}\text { Manager Mining - } \\
\text { Open Pit }\end{array}$ \\
\hline 5 & $\begin{array}{l}\text { Seismic monitoring and underground } \\
\text { extensometer }\end{array}$ & & $x$ & & $x$ & & & $\begin{array}{l}\text { Check system is } \\
\text { working, and verify it } \\
\text { is working correctly }\end{array}$ & $\begin{array}{l}\text { Senior UG } \\
\text { Geotechnical } \\
\text { Engineer }\end{array}$ & Daily & $\begin{array}{l}\text { Technical Support } \\
\text { Superintendent } \\
\text { UG }\end{array}$ \\
\hline 6 & $\begin{array}{l}\text { Seismic monitoring (pick up event); } \\
\text { provide timely information to open pit } \\
\text { supervisors }\end{array}$ & & $x$ & & $x$ & & & $\begin{array}{l}\text { Checkseismic } \\
\text { system; respond to } \\
\text { seismic reports }\end{array}$ & $\begin{array}{l}\text { Senior UG } \\
\text { Geotechnical } \\
\text { Engineer }\end{array}$ & $\begin{array}{l}\text { Review daily, } \\
\text { inform when large } \\
(\rightarrow \text { mag1) event } \\
\text { occurs }\end{array}$ & $\begin{array}{l}\text { Technical Support } \\
\text { Superintendent } \\
\text { UG }\end{array}$ \\
\hline
\end{tabular}

${ }^{2} \mathrm{H}=$ Hard Controls (Eliminate, Reducesubstitute, Enginee ing Barriers), $\mathrm{S}=\mathrm{Soft}$ Controls (Administrative, Signage, PPE, Procedures, Skills and Training) $\mathrm{P}=\mathrm{P}$ reventative, $\mathrm{M}=$ Monitoning $\mathrm{F}=$ First Response, $\mathrm{R}=$ Recover

\section{Figure 8 An example of the control management plan lists the existing controls and responsibilities}

The risk reduction plan was drafted to capture all identified actions and to ensure that additional controls were effectively applied where no controls existed or to reduce any remaining 'residual' risk down to an acceptable level. These residual risks were closed out if completed actions were sufficient to remove the risk or if effective controls were implemented. Where controls were implemented, these were then transferred to the control management plan. A sample of the risk reduction plan is shown in Figure 9.

\begin{tabular}{|c|c|c|c|c|c|}
\hline $\begin{array}{c}\mathrm{RRA}^{3} \\
\#\end{array}$ & Recommended Action & By Whom & Due Date & Comments & Accountability \\
\hline 9 & $\begin{array}{l}\text { Email propagation status report to OP supervisor at } \\
\text { least weekly which states depth to cave and } \\
\text { propagation rate }\end{array}$ & $\begin{array}{l}\text { Cave Interaction } \\
\text { Engineer }\end{array}$ & completed & $\begin{array}{l}\text { Weekly cave status report } \\
\text { implemented } \\
\text { (remove this line on next review) }\end{array}$ & $\begin{array}{l}\text { Planning Superintendent } \\
\text { OP }\end{array}$ \\
\hline 11 & $\begin{array}{l}\text { Establish and implement procedures / triggers to } \\
\text { investigate root cause of movement. Develop trigger } \\
\text { response plans for cave induced movement. }\end{array}$ & $\begin{array}{l}\text { Senior OP } \\
\text { Geotech Engineer }\end{array}$ & completed & $\begin{array}{l}\text { Highwall procedure has been } \\
\text { updated. Cave Tarp } \\
\text { implemented. } \\
\text { (remove this line on next review) }\end{array}$ & $\begin{array}{c}\text { Manager Mining - Open } \\
\text { Pit }\end{array}$ \\
\hline 27 & $\begin{array}{l}\text { Review strategy for mining step-out to assist cave } \\
\text { propagation. }\end{array}$ & $\begin{array}{l}\text { Senior UG } \\
\text { Geotech Engineer }\end{array}$ & completed & $\begin{array}{l}\text { Mining step-out not likely to } \\
\text { assist in cave propagation. } \\
\text { (remove this line on next review) }\end{array}$ & $\begin{array}{l}\text { Technical Support } \\
\text { Superintendent UG }\end{array}$ \\
\hline 28 & $\begin{array}{l}\text { Draw up procedures for borehole surveys and } \\
\text { monitoring above the cave after the cave exclusion } \\
\text { zone is triggered }\end{array}$ & $\begin{array}{l}\text { Principal Geotech } \\
\text { Engineer }\end{array}$ & completed & $\begin{array}{l}\text { Any procedure will require a } \\
\text { JSEA and the approval of the } \\
\text { Manager Mining- OP }\end{array}$ & $\begin{array}{l}\text { Manager Mining Open } \\
\text { Pit }\end{array}$ \\
\hline 29 & $\begin{array}{l}\text { Amend the Void Mining procedure to reference this } \\
M H M P \text { once the cave reaches } 300 \mathrm{~m} \text {. }\end{array}$ & $\begin{array}{l}\text { Principal Geotech } \\
\text { Engineer }\end{array}$ & Completed & $\begin{array}{l}\text { Liaise with the Void Control } \\
\text { Officers } \\
\text { (remove this line on next review) }\end{array}$ & $\begin{array}{l}\text { Manager Mining Open } \\
\text { Pit }\end{array}$ \\
\hline 32 & $\begin{array}{l}\text { Develop and implement an effective means of } \\
\text { monitoring movement and stability of the west wall } \\
\text { and the ramp. }\end{array}$ & $\begin{array}{l}\text { Senior OP } \\
\text { Geotech Engineer }\end{array}$ & Completed & $\begin{array}{l}\text { Photogrammetry and Prism } \\
\text { implemented. RADAR being } \\
\text { commissioned. } \\
\text { (remove this line on next review) }\end{array}$ & $\begin{array}{l}\text { Manager Mining - Open } \\
\text { Pit }\end{array}$ \\
\hline 33 & $\begin{array}{l}\text { Develop and implement trigger response plans for } \\
\text { movement in the west wall and the ramp. }\end{array}$ & $\begin{array}{l}\text { Manager Mining - } \\
\text { Open Pit }\end{array}$ & Completed & $\begin{array}{l}\text { Review and update the trigger } \\
\text { response plan in this document, } \\
\text { The TARP has been } \\
\text { implemented } \\
\text { (remove this line on next review) }\end{array}$ & General Manager \\
\hline
\end{tabular}

\section{Figure 9 An example of the risk reduction plan}

\subsection{TARP}

The TARP identified the trigger points assigned to lead indicators of potential hazards. These triggers provided warning that an escalation of the likelihood and /or consequence of an unwanted event may occur if action is not taken to manage the hazard. The triggers were linked to prescribed actions to be undertaken by the designated roles and reported to accountable roles. An example of the TARP is shown in Figure 10 below. 
TRIGGER, ACTION \& RESPONSE PLAN FOR CAVE INDUCED MOVEMENT (Cave within $200 \mathrm{~m}$ of breakthrough)

The following table outlines Triggers and Planned Responses for indications of cave induced movement. In the event a trigger is activated the planned response and required notification must be initiated.

\begin{tabular}{|c|c|c|c|c|c|}
\hline $\begin{array}{l}\text { Form of Review } \\
\text { (What is being } \\
\text { measured) }\end{array}$ & $\begin{array}{l}\text { Frequency } \\
\text { of Review }\end{array}$ & $\begin{array}{c}\text { Trigger or Key Decision } \\
\text { Point }\end{array}$ & Planned Response & Accountability & Notification \\
\hline Fill levels in VR9 & Daily & $\begin{array}{l}\text { Fill levels drop by more } \\
\text { than } 5 \mathrm{~m} \text { in a single event }\end{array}$ & $\begin{array}{l}\text { Clear exclusion zone and stop all access. } \\
\text { Inform supervisor, Open Pit Mining Manager, } \\
\text { Open Pit Mining Superintendent and Senior } \\
\text { Underground Ge otechnical Engineer. Review } \\
\text { cave monitoring data to verify air-gap. }\end{array}$ & $\begin{array}{l}\text { Void Control } \\
\text { Officers }\end{array}$ & $\begin{array}{l}\text { Manager Mining-Open } \\
\text { Pit }\end{array}$ \\
\hline \multirow[t]{2}{*}{ Fill levels in VR7 } & Daily & $\begin{array}{l}\text { Steady rate of movement } \\
\text { recorded in } 130 \text { Station } 2 \text {, } \\
\text { Anchors } 19 \& 20 \text { (I30 } \\
\text { extensometers) }\end{array}$ & $\begin{array}{l}\text { Clear exclusion zone. Inform supervisor, Open } \\
\text { Pit Mining Manager, Open Pit Mining } \\
\text { Superintendent and Senior Underground } \\
\text { Geotechnical Engineer. Review cave } \\
\text { monitoring data. }\end{array}$ & $\begin{array}{l}\text { OP Geotechnical } \\
\text { Engineer }\end{array}$ & $\begin{array}{l}\text { Manager Mining - Open } \\
\text { Pit }\end{array}$ \\
\hline & Daily & Significant rainfall event & $\begin{array}{l}\text { Clear exclusion zone. Inform supervisor, Open } \\
\text { Pit Mining Manager, Open Pit Mining } \\
\text { Superintendent and Senior Underground } \\
\text { Geotechnical Engineer. }\end{array}$ & $\begin{array}{l}\text { OP Geotechnical } \\
\text { Engineer/ Void } \\
\text { Control Officers }\end{array}$ & $\begin{array}{l}\text { Manager Mining - Open } \\
\text { Pit }\end{array}$ \\
\hline \multirow[t]{4}{*}{$\begin{array}{l}\text { Cave } \\
\text { propagation rate }\end{array}$} & \multirow[t]{2}{*}{ Weekly } & \multirow[t]{2}{*}{$\begin{array}{l}\text { Cave back cannot be } \\
\text { estimated and cave } \\
\text { propagation rate cannot be } \\
\text { verified }\end{array}$} & $\begin{array}{l}\text { Evacuate the cave exclusion zone. Review } \\
\text { hazards to the open pit. }\end{array}$ & $\begin{array}{l}\text { Manager Mining } \\
\text { - Open Pit }\end{array}$ & General Manager \\
\hline & & & $\begin{array}{l}\text { Review assumptions and rationale used in the } \\
\text { Risk Assessment. List impact of changes and } \\
\text { discuss with managers. }\end{array}$ & $\begin{array}{l}\text { Principal } \\
\text { Geotechnical } \\
\text { Engineer. }\end{array}$ & $\begin{array}{l}\text { Manager Mining - Open } \\
\text { Pit, } \\
\text { Manager Mining - } \\
\text { Underground, } \\
\text { General Manager } \\
\end{array}$ \\
\hline & \multirow[t]{2}{*}{ Weekly } & \multirow[t]{2}{*}{$\begin{array}{l}\text { Average propagation rate } \\
\text { for a week exceeds } \\
1.5 \mathrm{~m} / \text { day or drops below } \\
0.2 \mathrm{~m} / \text { day }\end{array}$} & $\begin{array}{l}\text { Check calculations and review all available } \\
\text { data. Verifying cave position, muck pile position } \\
\text { and propagation rate if safe to access surface } \\
\text { boreholes. }\end{array}$ & $\begin{array}{l}\text { Senior OP } \\
\text { Geotechnical } \\
\text { Engineer }\end{array}$ & $\begin{array}{l}\text { Principal Geotechnical } \\
\text { Engineer, } \\
\text { Manager Mining - } \\
\text { Underground }\end{array}$ \\
\hline & & & $\begin{array}{l}\text { Review assumptions and rationale used in this } \\
\text { document and in the risk assessment. List } \\
\text { impact of changes and discuss with managers }\end{array}$ & $\begin{array}{l}\text { Principal } \\
\text { Geotechnical } \\
\text { Engineer. }\end{array}$ & $\begin{array}{l}\text { Manager Mining - Open } \\
\text { Pit, } \\
\text { Manager Mining - }\end{array}$ \\
\hline
\end{tabular}

Figure 10 An example of the TARP showing a section of the plan when the cave had breached the $200 \mathrm{~m}$ pillar threshold.

This TARP was updated following a review of the risks after the cave breached the $150 \mathrm{~m}$ pillar exclusion zone and was reviewed again when surface deformation was noted.

\section{Communication}

Cave related information was communicated to supervisors through the daily production meeting. A cave interaction board was set-up in the meeting room and was reviewed as part of the meeting agenda. This board included the current TARP, geotechnical hazard map, the weekly status report, diagrams showing the current cave proximity to the pit and photographs showing the areas of the Western wall to be aware of in relation to the cave breakthrough.

A weekly cave status report was also issued, detailing any triggers which may have occurred in the week as well as a summary of monitoring data (Figure 11).

At the end of each month a review of the TARP was conducted and all triggers were detailed in a report, which also featured a summary of all caving data for the month. This report was reviewed and signed off by the principal geotechnical engineer, production superintendent, open pit mining manager and general manager. This process was essential as it ensured that all levels of management were aware of the cave performance for the month and could review triggered events (Figures 12). 
Cave Propagation Update - Week Ending 24/07/2009

Cave Propagation Trigger Status

\begin{tabular}{|c|c|}
\hline Cave Propagation & (;) \\
\hline Caving Rate & (:) \\
\hline Cave seismic events & (:) \\
\hline Large seismic events & (:) \\
\hline \multicolumn{2}{|l|}{ Cave Related Damage } \\
\hline Rockfalls due to cave movement & (:) \\
\hline Subsidence/cracking on breakthrough bench & (:) \\
\hline Prisms or Slope Stability Radar movement & (:) \\
\hline \multicolumn{2}{|c|}{$\begin{array}{l}\text { Comments: } \\
\text { Extensometer } 7 \text { (closest to the south ramp) is indicating movement at a } \\
\text { depth of } 140 \mathrm{~m} \text {. The movement previously detected by the radar on the } \\
\text { west wall at bottom of south ramp, has ceased. } \\
\text { Seismicity has decreased in the past two days and is a reflection of the } \\
\text { decreased production bogging underground. } \\
\text { Preparations are underway for the next Stage } 5 \text { shot, } 5480-037 \text {. }\end{array}$} \\
\hline (-) Needs Further Investigation & Bad \\
\hline
\end{tabular}

Issued By: Rebecca Dixon

Date: $24 / 07 / 2009$

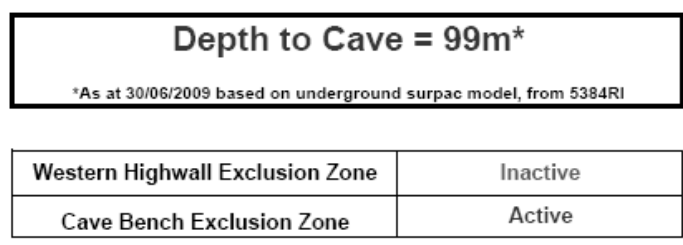

Outstanding Actions for the week

\begin{tabular}{|c|c|c|}
\hline Action & Responsibility & Due Date \\
\hline & & \\
\hline & & \\
\hline
\end{tabular}

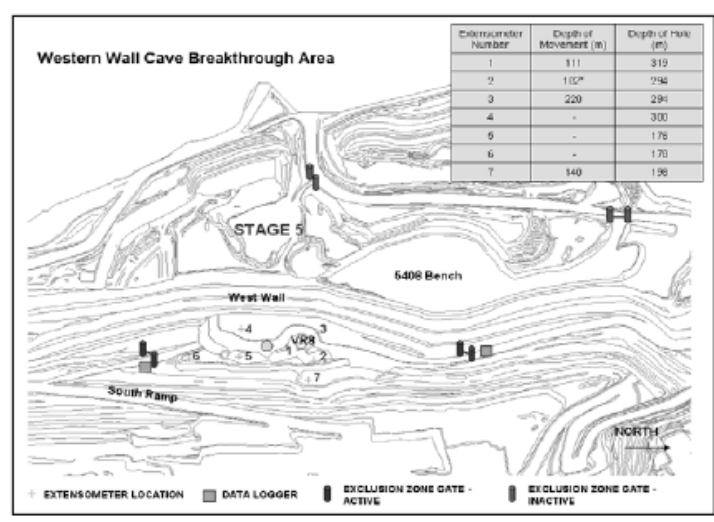

Figure 11 Weekly cave status report providing a quick overview

Trigger, Action \& Response Plan for Cave Induced Movement - May 2009

\begin{tabular}{|c|c|c|c|c|}
\hline Trigger or key decision point & $\begin{array}{l}\text { Has breach } \\
\text { occurred? }\end{array}$ & Accountability & Action required & Current Status \\
\hline $\begin{array}{l}\text { Fill levels in VR7 or VA9 drop by more then } 5 \mathrm{~m} \text { in a single } \\
\text { event }\end{array}$ & No & Void Control Officers & & (:) \\
\hline $\begin{array}{l}\text { Steady rate of movement recorded in } 130 \text { Station } 2 \\
\text { Anchors } 198220 \text {, which would indicated possibility for } \\
\text { slumping in VR7 }\end{array}$ & No & $\begin{array}{l}\text { Open Pit Geotechnical } \\
\text { Engineer }\end{array}$ & & (:) \\
\hline $\begin{array}{l}\begin{array}{l}\text { Significant rainfall event that would indicate possibility for } \\
\text { slumping in VR7 }\end{array} \\
\end{array}$ & No & $\begin{array}{l}\text { Open Pit Geotechnical } \\
\text { Engineer/ Void Control } \\
\text { Officers }\end{array}$ & & (-) \\
\hline $\begin{array}{l}\text { Cave back cannot be estimated and cave propagation } \\
\text { rate cannot be verified }\end{array}$ & No & $\begin{array}{l}\text { Open Pit Geotechnical } \\
\text { Engineer }\end{array}$ & & (:) \\
\hline $\begin{array}{l}\text { Average propagation rate for a week exceeds } 1.5 \mathrm{~m} / \text { day } \\
\text { or drops below } 0.2 \mathrm{~m} / \mathrm{day}\end{array}$ & No & $\begin{array}{l}\text { Open Pit Geotechnical } \\
\text { Engineer }\end{array}$ & & (2) \\
\hline $\begin{array}{l}\text { Cave stalled and/or air gap height is sufficient to create } \\
\text { the potential for instantaneous subsidence }\end{array}$ & No & $\begin{array}{l}\text { Senior Open Pit } \\
\text { Geotechnical Engineer }\end{array}$ & & (2) \\
\hline Subsidence noted on surface & No & $\begin{array}{l}\text { All personnel \& Work } \\
\text { area supervisors }\end{array}$ & & (:) \\
\hline Cracking noted on surface & No & $\begin{array}{l}\text { All personnel \& Work } \\
\text { area supervisors }\end{array}$ & & (:) \\
\hline $\begin{array}{l}\text { Irregular movement in deep hole extensometers detected } \\
\text { i.e. movement in anchors closer to surface or a large } \\
\text { increase in movement rate }\end{array}$ & Yes & $\begin{array}{l}\text { Open Pit Geotechnical } \\
\text { Engineer }\end{array}$ & $\begin{array}{l}\text { Due to iregular movement in extensometer } 2 \text {, an exclusion } \\
\text { zone was establishod around this instrument and the cave } \\
\text { apex on the breakthrough bench. Preloading was then } \\
\text { completed with trucks not permitted to enter this area. }\end{array}$ & $\begin{array}{l}\text { Irregular movement continues on this } \\
\text { instrument. Seismic datat is being used to } \\
\text { verify the cave location around extensometer } 2\end{array}$ \\
\hline $\begin{array}{l}\text { Evidence of rock noise, ground vibration or movement of } \\
\text { open pit walls above the cave or near the Graben Fault }\end{array}$ & Yes & $\begin{array}{l}\text { All personnel \& Work } \\
\text { area supervisors }\end{array}$ & 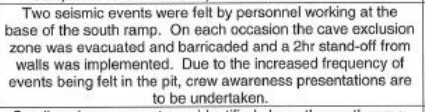 & (:) \\
\hline $\begin{array}{l}\text { Wall movement indicated by monitoring instrumentation } \\
\text { within cave influence zone. (Prisms or radar) }\end{array}$ & Yes & $\begin{array}{l}\text { Open Pit Geotechnical } \\
\text { Engineer }\end{array}$ & $\begin{array}{l}\text { Small scale movement was identified above the south ramp, } \\
\text { below the cave breakthrough bench. The movement was } \\
\qquad 1 \mathrm{~mm} / \text { dday. }\end{array}$ & $\begin{array}{c}\text { Movement has since slowed to approximatoly } \\
0.5 \mathrm{~mm} / \text { day and the area continues to be } \\
\text { monitored closely. }\end{array}$ \\
\hline
\end{tabular}

This report has been reviewed by:

\begin{tabular}{|c|c|c|c|}
\hline Date & Name (printed) & Role & Signature \\
\hline 1816109 & Mark Mitchell & General Manager & Whicha \\
\hline $16 / 06 / 09$ & Tom Lynch & Open Plt Mine Manager & Th $\mathrm{AHL}_{2}$ \\
\hline $16 / 06 / 2009$ & Uday Singh & Principal Geotechnical Engineer & Approved via e-mail \\
\hline & Lukas Gmelig / Warren Hurihanganui & Open Pit Superintendent & \\
\hline $16 / 06 / 2909$ & Luke Cerny / Jamie-Aisop & Senior Planning Engineer & 1/2h \\
\hline $16106 / 2009$ & Rebecca Dixon & Geotechnical Engineer - Cave Interaction & $1 / 2$ \\
\hline
\end{tabular}

Figure 12 The front page of the Monthly TARP report. The back page of this A3 size form shows related data from instrumentation, monitoring and analysis 
At each revision of the TARP, a training program was rolled out where the workforce was made aware of the identified hazards, new controls and response actions.

The crew were also presented with regular updates during shift change so that past triggers, changes in cave, subsidence and response actions could be discussed. This also provided the crew with an opportunity to provide feedback if they had concerns.

\section{Conclusion}

The interaction between the Telfer SLC cave and the Main Dome Pit was unique in that the pit continued to operate while a deep cave propagated into the pit wall, some $70 \mathrm{~m}$ from the South Ramp. There was little available case history or data of similar situations from other mines and as such a conservative interaction management strategy was adopted. Strategic plans such as developing a Northern Ramp have proved to be invaluable in safe operation of the pit while the South Ramp was being influenced by the cave. Preloading and backfilling of the subsidence crater are expected to assist in limiting the size of the crater and sloughing of the Western wall above the cave.

Geotechnical instrumentation, monitoring and data interpretation were key foundations for building effective controls and identifying changed conditions early enough to take proactive actions. Preloading of the breakthrough bench presented a few unique challenges in regards to instrumentation and subsidence monitoring.

A stepped approach was used for hazard management where numerous hold and review points were set in order to assess the hazards and modify the controls as the cave propagated and changed conditions were identified. These were based on a qualitative risk assessment which was updated at key milestones.

The use of the MHMP and especially the TARP for managing changed conditions and proactively managing hazards has been very effective so far.

\section{Acknowledgements}

The Telfer cave interaction could not be managed successfully without strong commitment and teamwork from both the underground and open pit operations. The authors wish to acknowledge the excellent contribution to this project from both the underground and open pit geotechnical personnel and from the mine interaction department. We would also like to thank the Newcrest Mining Limited for this opportunity to publish this paper.

\section{References}

Di Giovinazzo, M. and Singh, U. (2010) Instrumentation and monitoring of cave initiation at Telfer Mine, in Proceedings 2nd International Symposium on Block and Sublevel Caving (Caving 2010), Y. Potvin (ed), 20-22 April 2010, Perth, Australia, Australian Centre for Geomechanics, Perth, pp. 145-156.

Dixon, R.A., Singh, U. and McArthur, C. (2010) Interaction between a propagating cave and an active pit at Telfer Mine - Part II: monitoring interaction, in Proceedings 2nd International Symposium on Block and Sublevel Caving (Caving 2010), Y. Potvin (ed), 20-22 April 2010, Perth, Australia, Australian Centre for Geomechanics, Perth, pp. 321-331.

Flores, G. and Karzulovic, A. (2000) Geotechnical Guidelines for Transition from Open Cut to Underground Mining: Benchmarking report, report to International Caving Study II, Julius Kruttschnitt Mineral Research Centre, Brisbane, Australia.

Newcrest Mining Ltd (2009) Our Operations, Telfer, viewed 8 November 2009, http://www.newcrest.com.au. 